\title{
1. Introduction to National Courts and Preliminary References to the Court of Justice
}

\section{SETTING THE SCENE}

The ECJ ${ }^{1}$ has been both applauded and criticized for being an essential protagonist of European integration and for shaping, transforming and constitutionalizing EU law. ${ }^{2}$ The ECJ has primarily achieved this through its cooperation with national courts in the context of the preliminary reference procedure under Article 267 of the Treaty on the Functioning of the European Union (TFEU). ${ }^{3}$ Most of the major EU law principles were developed by the ECJ in response to questions from national courts acting, in the words of current President of the ECJ Lenaerts, as the 'arms of EU law'. ${ }^{4}$ It is thus for good reason that the procedure has been referred to as the 'jewel in the crown' or the 'most fundamental element in the constitutional architecture' of the EU legal order. ${ }^{5}$ The ECJ presents it as the 'keystone' of the judicial system in the EU. ${ }^{6}$ However, the effectiveness of the preliminary reference procedure depends on the willingness of national courts to utilize it in practice. ${ }^{7}$ National courts are thus indispensable 'lynchpins' of the system of EU judicial protection and important guarantors of the effectiveness of EU law and the rights of individuals. ${ }^{8}$ Their ability to refer 'constitutes the very essence of the [EU] system of

1 'ECJ' is used to refer to the Court of Justice, one of the two courts of the Court of Justice of the European Union, in addition to the General Court. See Article 19(1) of the Treaty on European Union.

2 Weiler 1994; Alter 2002; Stone Sweet 2004; Broberg and Fenger 2013, 488; Sarmiento and Weiler 2020; Vauchez 2010.

Alter 2002, 227; Wind et al 2009, 64.

Tridimas and Tridimas 2004, 127.

Craig and de Búrca 2015, 464; Weiler 1987, 366.

Opinion 2/13, EU:C:2014:2454, para 176; Craig 2001, 559.

Arnull 2012, 119; Lenaerts 2019, 4.

8 See also Case C-33/76 Rewe EU:C:1976:188, para 5; Case C-45/76 Comet EU: C:1976:191, para 12; Case C-224/01 Köbler EU:C:2003:513, para 35; Opinion 2/13, EU:C:2014:2454, para 175. 
judicial protection'. ${ }^{9}$ The ECJ underlined the importance of the preliminary reference procedure, which accounts for 66 per cent of all its cases, by noting that through this procedure, the ECJ and national courts 'form a network that brings EU law and rights to the citizen's doorstep'. ${ }^{10}$

The procedure has nonetheless come under significant pressure in the last decade. Some maintain that the procedure has become a victim of its own success, given the large influx of new cases since the mid-2000s. ${ }^{11}$ It has even been argued that the system could collapse without intervention. ${ }^{12}$ To date, however, the ECJ has managed to prevent this and has not (yet) buckled under the pressure of the growing backlog of cases - although this heavy caseload is not without consequences for the quality of the reasoning in the judgments. ${ }^{13}$ There are signs that national courts have become more critical of their interaction with the ECJ. ${ }^{14}$ Two problems stand out in this regard. First, national courts - and especially constitutional courts ${ }^{15}$ - are frequently unwilling to refer or simply lack sufficient knowledge of EU law and the preliminary reference procedure. ${ }^{16}$ This failure to refer could mean that national courts end up applying their own interpretation of EU law, thus diverging from that of the ECJ and resulting in a breach of EU law. ${ }^{17}$ Second, the implementation of ECJ judgments is not straightforward. It is an often-told story that most constitutional courts fail to respect the primacy of EU law. ${ }^{18}$ National courts also feel that they do not always receive helpful guidance because some ECJ judgments are insufficiently motivated or do not provide a clear answer to the questions posed. ${ }^{19}$ This has also resulted in instances of non-compliance with EU law. Hofmann referred to a 'pushback' or 'backlash' against the ECJ, which has been more significant than is commonly understood. ${ }^{20}$ The most obvious case is the follow-up judgment of the German Federal Constitutional Court

Case C-300/99 P Area Cova \& Ors v Council EU:C:2001:71, para 54.

LinkedIn message of the ECJ, 25 October 2020.

De la Mare and Donnelly 2011, 363-407; Davies 2006, 210-44.

Vink et al 2009, 23.

13 Sharpston 2014, 765; Weiler 2013, 235; Jacobs et al 2019, 1216; BVerfG 2 BvR $859 / 15$, paras $116-18$.

14 Micklitz 2005, 426; Pollack 2018; Gallo 2019; Dyevre 2013; Bobek 2014a; Pollicino 2014; Pérex 2014; Guastaferro 2017, 394.

15 Claes 2015; Bobíc 2017; Martinico 2010; Saurugger and Terpan 2017, 108-16. On the Belgian and Austrian Constitutional Courts, which have been relatively eager to refer and faithful in terms of compliance, see Burgorgue-Larsen 2015; Cloots 2010; Baraggia 2015.

16 Bobek 2013b, 212-13; Arnull 1989.

17 Tridimas 2003, 47.

18 Davies 2018, 323.

19 De Werd 2015b, 154; Arnull 2012, 131.

20 Hofmann 2018. 
in Weiss, in which the ECJ ruling was found to be ultra vires. ${ }^{21}$ Weiss shows that the earlier Landtová judgment, in which the Czech Constitutional Court reached a similar conclusion, was not an 'isolated incident'. ${ }^{22}$ Other notable examples include the Danish Supreme Court's disobedience after Dansk Industri; and the rhetorical questions posed by the German Constitutional Court in Gauweiler, in which it threatened not to comply with the ECJ ruling if it diverged from its own interpretation. ${ }^{23}$ One can also think of less explicit illustrations of a difficult (or absent) dialogue, such as in the Spanish case of Melloni. ${ }^{24}$

If these two problems (non-referral and non-compliance) are real and remain unaddressed, this could erode the authority of the ECJ and affect the application and hence the effectiveness of EU law, ultimately undermining the entire European integration project. ${ }^{25}$ It is thus important to identify how national courts engage with the ECJ and how the preliminary reference procedure works in practice. Little is known, however, about this interaction and the different stages: question, answer and follow-up. This raises four specific research questions: why do national courts refer preliminary references to the ECJ (question)? How does the ECJ deal with and answer those questions, including from the perspective of the referring court (answer)? And what does the referring court subsequently do with those answers (follow-up)? The fourth research question relates to so-called feedback loops: to what extent is there a relationship between the motives of judges (not) to refer and their level of satisfaction with their interaction with the ECJ and the answers to their questions?

The academic relevance of this book is threefold, as will be revealed below. First, it fills an empirical gap (section 1.1). Second, it reflects on the (in)validity of dominant theoretical perspectives (section 1.2). In doing so, it offers new approaches and insights that also have practical relevance that goes beyond the three EU Member States studied (section 1.3).

\subsection{Scientific Relevance: Filling Four Empirical Gaps}

The first question, concerning the motives and factors behind references, has received a considerable degree of attention, albeit primarily in quantitative

Case C-493/17 Weiss EU:C:2018:1000; BVerfG 2 BvR 859/15.

Case C-399/09 Landtová EU:C:2011:415; Dyevre 2016, 109.

23 Case C-441/14 Dansk Industri EU:C:2016:278; Case C-62/14 Gauweiler EU: C:2015:400; Klinge 2016; Rask Madsen et al 2017; Šadl and Mair 2017; Mayer 2014; Tridimas and Xanthoulis 2016.

24 Case C-399/11 Melloni EU:C:2013:107; Pérez 2014.

25 Tridimas 2015, 404. 
terms. Statistical studies have mainly tested structural factors at the Member State level in order to explain why the courts in some Member States refer more often than those in others. Such factors include the level of gross domestic product; the willingness to litigate; support for European integration; the existence of judicial review; and the monist or dualist nature of the legal system. ${ }^{26}$ Despite ample research, there is still no consensus among these studies. This is also the case because the correlations between several structural factors and the number of preliminary references is 'not impressive', as several outliers or factors work in opposite directions. ${ }^{27}$ For example, there is disagreement as to whether judges in smaller Member States are more eager to refer. ${ }^{28}$ There is also no consensus as to whether references are less likely in majoritarian democracies than in constitutional democracies. ${ }^{29}$ Another disadvantage of statistical studies relying on an aggregated number of references is that they ignore important dynamics. ${ }^{30}$ Differences over time and within Member States - even within courts - are often overlooked..$^{31}$ Structural factors also do not account for differences across legal fields and policy areas. ${ }^{32}$ The largely (quantitative) studies conducted so far have focused on explaining the determinants of European integration rather than the theme of judicial decision making. ${ }^{33}$ This means that 'the most important puzzle confronting scholars' in the field of EU law has not yet been solved. ${ }^{34}$ Rather than examining these aggregate-level factors, this book addresses the motives of individual judges as a way to fill the gaps in earlier research. It contributes to the growing literature on judicial decision making and engages with the findings of other empirical qualitative studies based on interviews with judges in Denmark, Poland and Spain, and more recently in Italy, Germany, France, Croatia, Slovenia and Sweden. ${ }^{35}$ This literature will be presented in section 3 .

26 Stone Sweet and Brunell 1998; Tridimas and Tridimas 2014; Nyikos 2003; Carruba and Murrah 2005; Wind et al 2009; Sigafoos 2012.

27 Broberg and Fenger 2013, 500; Vink et al 2009, 22; Hornug and Voigt 2015, 293.

28 Contrast, for example, Groenendijk 2015; Wind 2010, 1047; Wind et al 2009, 63 with Broberg and Fenger 2013; Vink et al 2009.

29 Contrast, for example, Wind et al 2009, 63 with Groenendijk 2015; Fenger and Boberg 2013, 491; Lampach and Dyevre 2019.

30 Leijon 2020.

31 Cf Stone Sweet and Brunell 1998, 88; Dyevre 2013, 166; Kelemen and Pavone 2016, 1119.

32 Golub 1996, 375.

33 Lampach and Dyevre 2019.

34 Stone Sweet and Brunell 1998, 73.

35 Jaremba 2012; Mayoral 2013; Mayoral and Pérez 2018; Pavone 2018; Glavina 2019; Leijon 2020. 
There have been fewer studies on the second question (answer), concerning the national courts' appraisals of their interaction with the ECJ and the resulting judgments. We therefore know surprisingly little about what national courts (truly) think of ECJ judgments or the perceived legitimacy of the ECJ. ${ }^{36}$ The following observation of current Advocate General (AG) Bobek, dating from 2013, still holds true: "very little or nothing at all is known ... whether or not national courts are satisfied with the Court's decision(s) once they receive them, whether they consider them authoritative, and whether the Court's case law is in fact followed' ${ }^{37}$ Pollack pointed to the absence of systematic information about the attitudes and beliefs of national judges regarding the ECJ's legitimacy, and noted that scholars have instead relied on indirect evidence - namely, the behaviour of judges in terms of referring and compliance. ${ }^{38}$ This book will reveal that reliance on such evidence is problematic. The generally high level of follow-up actually camouflages the dissatisfaction among national judges as to the quality of their interaction with the ECJ and the resulting judgments. Van Gestel and de Poorter recently drew similar conclusions in relation to the ten highest administrative courts. ${ }^{39}$

There is little recent research on the third question, dealing with the follow-up to ECJ judgments, although some older studies found high rates of implementation of 90 to 92 per cent. ${ }^{40}$ Little has changed since Nyikos observed that research on national court implementation is 'still in its infancy' and 'the silent elephant' in the room. ${ }^{41}$ This can be explained by the difficulty in accessing such follow-up judgments, and the fact that such judgments are not collected by the ECJ or presented on the Curia website. ${ }^{42}$ On the one hand, there is a pervasive belief that ECJ judgments are widely accepted and followed..$^{43}$ On the other hand, however, more recent - often rather anecdotal - work has found that implementation is not always achieved, and that many of the principles in the ECJ case law have not been acted upon by national courts. ${ }^{44}$ Nyikos, for instance, pointed to outcomes other than the full application of the ECJ judgment, such as partial application; a reinterpretation of the facts so that the ECJ judgment does not apply; re-referral to the ECJ; and

\footnotetext{
Cf Wallerman Ghavanini 2020a, 196.

Bobek 2013b, 212-13.

Pollack 2018.

Van Gestel and de Poorter 2019.

40 Older single country studies include Schwarze 1988; Korte 1991; Mayj 1993;

41 Nyikos 2003, 402. Cf de Búrca 2020; Bobek 2014a; Hofmann 2018.

42 Van Gestel and de Poorter 2019, 99.

43 Weiler 2013, 235.

44 Bobek 2013b; Fierstra 2002; Van Harten 2013, 123; Davies 2012, 81 and 89.
} Wils 1993. 
concealed or open non-compliance. ${ }^{45}$ Other scholars noted that judges often consider ECJ judgments to be complex, lengthy and unreadable, and difficult to apply to the facts of the national case. ${ }^{46}$ Alter also argued against the assumption that ECJ judgments are easily accepted by national courts. ${ }^{47} \mathrm{~A}$ few empirical studies have examined follow-up in particular legal areas, such as environmental law; but it is unclear whether these findings can be extrapolated to other fields. ${ }^{48}$ This book thus acts upon the explicit request of Stone Sweet, who observed that:

one of the most important, and largely uncharted, areas of research on legal integration concerns problems and inconsistencies in national application and adjustment to the Court's case law ... We still desperately need comparative, contextually-rich case studies that blend the lawyer's concern with doctrinal evolution, and the social scientist's concern with explanation, in a sustained way. ${ }^{49}$

There has been even less work on the fourth question, about the feedback relationship between the motives of judges (not) to refer and their level of satisfaction. Scholars and judges alike have hinted at the existence of such an intuitively plausible relationship by noting that a judge who feels that $\mathrm{s} / \mathrm{he}$ has not received helpful guidance might refrain from sending future references to the ECJ. ${ }^{50}$ Alter pointed to a negative feedback loop in relation to litigants when they are subject to an unfavourable ECJ judgment, possibly increasing their reluctance to bring future disputes to court. ${ }^{51}$

This book thus provides insights into four questions that have received little attention to date - especially the last three questions on the appraisal of the ECJ's answer, the follow-up and feedback loops.

\subsection{Offering a New, Truly Interdisciplinary Approach}

This book combines two (qualitative) research methods that have not been employed frequently thus far. The legal literature to date has primarily relied on a legal-doctrinal analysis of national court and ECJ judgments, without

\footnotetext{
Nyikos 2003, 399-401.

Jaremba 2013; Wallis 2008, 26; Nowak et al 2011; de Werd 2015b, 152.

Alter 1998, 233-34.

48 Recent exceptions are Squintani and Annink 2018; Squintani and Rakipi 2018; Squintani and Kalisvaart 2020.

49 Stone Sweet 2004, 197 and 241; Stone Sweet 2010, 32; Davies 2012, 78.

50 Vink et al 2009, 8; Norrgård 2016, 196; de Witte 2016, 25; de Werd 2015b, 154; Arnull 2012, 131; Tridimas 2011, 755; Jacobs et al 2019, 1218; Sharpston 2014, 766.

51 Alter 2000, 512.
} 
paying much attention to extra-legal considerations..$^{52}$ The emphasis has also been on analysing the case law of the ECJ in isolation from the actual reference of the national court and the subsequent implementation by that same court. ${ }^{53}$ This book shows that the understanding of the interaction between the ECJ and national courts cannot merely be based on the final judgments alone. Instead, we need to get 'into the heads and minds' of the key actors involved. Interviews are one of the best tools available to achieve this objective.

There have been a handful of (primarily social science) studies relying on interviews with judges in order to identify the motives and factors that inform the decision to refer ${ }^{54}$ Many of these empirical studies nonetheless relied extensively on interviews, without engaging substantively with legal considerations and the legal context. A clear appraisal of the law and the legal context is essential for a proper interpretation and triangulation of the interview data. Interviews have not been conducted with respect to the other three research questions: the national court's appraisal of the ECJ answers, follow-up and feedback loops. ${ }^{55}$

This book thus bridges two disciplines through an interdisciplinary approach. It complements the legal literature with a focus on the 'law in action'; and it adds to social science studies that have principally relied on quantitative research or on interviews without triangulating these findings with the actual judgments of both national courts and the ECJ. In doing so, it provides practical insights and examples, and enriches the rather abstract and theoretical literature.

Another novel aspect is that this book focuses on courts that have thus far received little in-depth attention, since the (legal) literature has primarily concentrated on just a handful of prominent constitutional courts (especially the German, Italian, Spanish and French courts) and their interaction with the ECJ. ${ }^{56}$ Very little work has referred to other courts, especially the lower courts, until recently. ${ }^{57}$ Attention has hitherto focused on high-profile cases, such as those discussed earlier in this chapter - Weiss, Gauweiler, Dansk Industri, Taricco and Melloni - while more routine, day-to-day cases have received limited, if any, attention. ${ }^{58}$

\footnotetext{
Dyevre 2013, 142.

Castillo Ortiz 2017.

54 Jaremba 2012; Mayoral 2013; Mayoral and Pérez 2018; Pavone 2018; Glavina

55 An exception is the recent study of van Gestel and de Poorter 2019.

56 Cf van Gestel and de Poorter 2019, 3. Eg, Baraggia 2015; Dani 2017b, 786.

57 Cf Arnold 2020, 1087; Pavone 2018.

58 Cf Pollack 2017, 592.
} 2019; Leijon 2020. 
This book provides original reflections on dominant (theoretical) perspectives that have thus far received limited attention. First, it shows that there are differences not only between EU Member States with respect to the use of the preliminary reference procedure, but also within Member States between different courts, and even among the judges within these courts. Second, the book reveals that the high implementation rate of ECJ judgments by the referring courts suggests satisfaction, but actually conceals some dissatisfaction with those judgments. ${ }^{59}$ Even in the Netherlands, where the courts are traditionally compliant interlocutors, there has been considerable criticism with regard to the functioning of the procedure and the resulting ECJ judgments.

\subsection{Practical Relevance}

This book is obviously relevant to Dutch, Irish and (even) UK legal practice. It is worth mentioning that the UK courts will be able to refer questions about specific areas of EU law to the ECJ for at least a decade after the actual withdrawal of the UK from the EU following Brexit. However, the practical relevance extends beyond these three EU Member States because of the book's explicit grounding in existing theories and its engagement with recent empirical studies (section 3). The book also profits from a complementary $\mathrm{PhD}$ project carried out by Claassen involving the Netherlands, Austria and Germany. ${ }^{60}$

This book is relevant to legal practitioners, as well as judges and legal secretaries of national courts and the ECJ. The concluding Chapter 8 offers some suggestions for the ECJ and national courts to mutually improve their interaction. First, legal practitioners will benefit from the insights provided as to why courts decide (not) to refer. They will thus be better able to tailor to their strategies based on real examples of successful cases. The findings presented in this book have greatly benefited from discussions with legal practitioners, such as lawyers and representatives of non-governmental organizations (NGOs), and presentations given to a varied audience in past years. The interaction with these actors has also contributed significantly to the (interpretation of) data.

Second, the ECJ could learn from the perspectives and experiences of national court judges gained from their use of the procedure, their interaction and their follow-up to ECJ judgments. The findings, especially in Chapter 5, underscore the need for the ECJ to consider more carefully how it can maintain its legitimacy in a world in which not only its interlocutors, but also the wider

59 Cf Hofmann 2018.

60 He examined the motives of courts (not) to refer in four specific legal areas: competition law, criminal law, consumer law and asylum law, Claassen 2021. 
population and Member State governments, have become more critical. ${ }^{61}$ The conclusion of this book offers several suggestions for improvements. These suggestions are also based on the practice and experience in the UK, which are presented as 'lessons learned' regarding the state of affairs of EU law and the functioning of the preliminary reference procedure and the ECJ.

Third, national courts can benefit from good practices revealed in the research concerning which questions they should (not) refer, and can learn how they could best formulate the order for reference. The book also holds up a mirror to national judges' (dis)satisfaction with the interaction by offering comparative impressions.

\section{PRELIMINARY REFERENCE PROCEDURE: LEGAL FRAMEWORK}

The preliminary reference procedure that is currently laid down in Article 267 TFEU was one of the first instances of cooperation between an international court and national courts. ${ }^{62}$ Its design was based on similar reference systems in Italy and France, where lower courts can request a preliminary ruling from the constitutional court. The procedure, initially included in Article 41 of the Treaty establishing the European Coal and Steel Community, was rather limited in scope, allowing a reference only 'when the validity of acts of the High Authority or the Council is contested in litigation before a national tribunal'. Over the years, this scope was widened to include the validity of acts of a broader range of EU institutions, as well as the interpretation of the Treaties - including the Charter of Fundamental Rights - secondary EU law and even international agreements concluded by the EU. This means that the procedure currently covers the entire body of EU law, with the exception of the Common Foreign and Security Policy. ${ }^{63}$

Article 267 TFEU requires national courts or tribunals to refer to the ECJ if a question is raised about the interpretation or validity of EU law when 'there is no judicial remedy under national law', provided that 'a decision on the question is necessary to enable it to give judgment'. As will be discussed in Chapter 2 , the latter delimitation is crucial because courts are not obliged to refer if they can decide the case on the basis of national law, or if the particular facts of the case are such that they do not require a reference. This obligation applies to the highest court or courts in Member States - a supreme (administrative)

Kelemen 2016, 137 and 140.

Broberg and Fenger 2014, 2.

Art 275 TFEU; however, the ECJ broadened the possibilities to refer in Case C-72/15 Rosneft EU:C:2017:236. 
court and/or a constitutional court. However, it could happen that a 'lower' court is obliged to refer in a particular case in which there is no remedy, even though it enjoys discretion in most other cases. The obligation to refer applies, for example, to sub-district court cases in the Netherlands because, pursuant to Article 332(1) of the Code of Civil Procedure, no appeal is possible against judgments in cases where the claim amounts to less than $€ 1750$ or in particular disputes about visas. The situation is different in the UK and Ireland, where the Supreme Court in principle always has the last word in all cases. ${ }^{64}$

The term 'lower court' is thus not entirely accurate, since the obligation in Article 267 TFEU does not concern the status of a court as such, but rather the stage of the proceedings. This book will nonetheless use the term 'lower court' and 'highest court' to refer to the position of the court in the judicial hierarchy. The former is used to refer to a court that only has discretion to refer, while the latter is used to refer a court that is obliged to refer unless otherwise stated. There is one exception to the discretion of lower courts to refer - namely, when the validity of (secondary) EU law is at stake. The ECJ made clear in Foto-Frost that courts are obliged to refer if they have doubts about the validity of EU law. ${ }^{65}$ The coherence of the EU legal system and the uniformity of EU law require that the power to declare an EU act invalid be reserved to the ECJ.

There are two exceptions to the obligation of the highest courts, which are commonly referred to as the CILFIT exceptions. The highest courts are not obliged to refer where the ECJ has 'already dealt with the point of law in question' (acte éclairé), or where 'the correct application of [EU] law may be so obvious as to leave no scope for any reasonable doubt' (acte clair). ${ }^{66}$ The ECJ presented quite a strict framework for national courts in its CILFIT judgment of 1982. National courts 'must be convinced that the matter is equally obvious to the courts of the other Member States and to the Court of Justice' ${ }^{67}$ Before reaching that conclusion, they must consider the characteristic features of EU law and compare, among other things, different language versions of the provision(s) of EU law. ${ }^{68}$ As will be discussed in Chapters 2 and 8, there is

${ }^{64}$ Before the entry into force of the $33^{\text {rd }}$ constitutional amendment in Ireland in 2014, the High Court was obliged to refer in particular areas of law, including planning and refugee law. Eg s 5(3) of the Illegal Immigrants Act 2000; s 50A(7) and s 50A(11) of the Planning and Development Act 2000. Article 34.5.3 of the Irish Constitution provides that the Supreme Court may grant leave if it is satisfied that the 'decision involves a matter of general public importance' or when it serves 'the interests of justice'.

65 Case 314/85 Foto-Frost EU:C:1987:452.

66 Case 283/81 CILFIT EU:C:1982:335, paras 14 and 16.

67 Ibid, para 16.

68 Ibid, paras 17-20. 
a discussion in the literature, as well as among judges, as to the feasibility of the notions of 'convinced' and the specific CILFIT requirements. ${ }^{69}$

Two enforcement mechanisms can be invoked where a highest court fails to comply with its obligations under Article 267 TFEU. Their practical effects are limited, however. First, the European Commission can initiate an infringement procedure on the basis of Article 258 TFEU. In the 2018 case of Commission $v$ France, for the first time ever, the ECJ determined that there was a violation of Article 267 TFEU due to the failure of the French Council of State to refer in an infringement procedure. ${ }^{70}$ Previously, the ECJ had only found violations relating to the misapplication of EU law by national courts more indirectly. The first infringement mechanism can be seen in action in an infringement case against Italy, in which the ECJ established that there had been a breach of EU law because the legislature had failed to amend a particular law that had been misinterpreted and misapplied by the administration and a significant number of courts, including the Supreme Cassation Court. ${ }^{71}$ Unlawful case law was thus one of the elements taken into account; but in the end, it was the legislature that was held responsible for its failure to take action. This also happened in a later procedure against Spain concerning the implementation of the Sixth Value Added Tax (VAT) Directive. In this case, Spain invoked the difficulty that the highest Spanish court had experienced in issuing judgments on which the policy was based as justification for the failure to fulfil its obligations under EU law. ${ }^{72}$ In both cases, the actions of the judiciary were not assessed from the perspective of Article 267 TFEU and were taken into account only in a more indirect way when the ECJ had to determine whether the Member State had, as such, infringed EU law. This illustrates the Commission's reluctance to pursue an alleged breach of EU law by independent national judiciaries directly. In the past, the Commission took action only once in relation to Article 267 TFEU in the context of an infringement procedure. In 2004, it initiated proceedings against Sweden because of the low number of references and the lack of a statement of reasons for its refusals to refer. Following a change in Swedish law, the Commission dropped the case. As a result, the case was never brought before the ECJ. ${ }^{73}$

A second enforcement mechanism is an action for state liability, which can be started by natural or legal persons before a national court in case of the failure of the highest court to refer. The ECJ determined in Köbler that the principle of state liability, as developed by the ECJ since Francovich, also

\footnotetext{
Broberg and Fenger 2014, 255; Tridimas 2003, 42-44.

Case C-416/17 Commission v France EU:C:2018:811, para 111; Turmo 2019.

Case C-379/10 Commission v Italy EU:C:2011:775.

Case C-154/08 Commission v Spain EU:C:2009:695.

Bernitz 2010.
} 
applies to situations of non-referral by the highest court. ${ }^{74}$ The practical effects of Köbler are limited because the ECJ set the bar relatively high, and because there is an aversion within the national legal culture in relation to the notion of judicial liability. ${ }^{75}$ In this case, the Austrian Supreme Administrative Court withdrew questions that had previously been referred because they were no longer necessary for the settlement of the dispute. It did so after being asked by the ECJ registry whether it wished to uphold the questions in the light of an ECJ ruling on the same issue. Mr Köbler disagreed with the final decision of the ECJ and proceeded to claim damages before a lower court. The ECJ found that the Austrian court should not have withdrawn its reference and was instead obliged to uphold it, because the ECJ had not yet given its ruling on the matter and the Austrian court 'was not entitled to take the view that resolution of the point of law at issue was clear from the settled case-law of the Court or left no room for any reasonable doubt' ${ }^{76}$ In spite of this, the ECJ did not consider the Austrian court's error to be sufficiently serious and found that it was not a 'manifest' violation. The ECJ substantiated this by pointing out that the disputed issue was not explicitly regulated by EU law. The question also had not been answered previously in other ECJ case law; nor was it an obvious violation. The ECJ concluded that state liability 'can be incurred only in the exceptional case where the court has manifestly infringed the applicable law'. ${ }^{77}$ It pointed to essential factors that set the bar fairly high for a finding of an actionable violation, including the question of whether the violation was committed intentionally and how excusable the error of law was.

There is discussion in the literature as to whether the ECJ has relaxed the CILFIT requirements in recent years. The ECJ adopted a more pragmatic reading of CILFIT in the Dutch cases $X$ and Van Dijk. It ruled that the highest court is not required to make a reference to the ECJ on the sole ground that a lower national court referred a case involving the same legal issue. In other words, the highest court can stick to its earlier determination of an acte clair, and the fact that a lower court may entertain doubts regarding the ruling does not change this. ${ }^{78}$ However, the ECJ decided on the same day in Ferreira da Silva that the Portuguese Supreme Court could not have determined an acte clair because of conflicting decisions of lower Portuguese courts and because

\footnotetext{
74 C-224/01 Köbler EU:C:2003:513. Cf Case C-173/03, Traghetti del Mediterraneo EU:C:2006:391; Case C-379/10 Commission v Italy EU:C:2011:775.

75 Dougan 2020, 55. However, see recently Case C-620/17 Hochtief EU:C:2019: 630; Case C-362/18 Hochtief EU:C:2019:1100.

76 C-224/01 Köbler EU:C:2003:513, para 118.

77 Ibid, para 53.

78 Joined Cases C-72/14 and C-197/14 X and Van Dijk EU:C:2015:564.
} 
of difficulties of interpretation encountered in various other Member States. ${ }^{79}$ The ECJ suggested that the Portuguese court's failure to refer might amount to a violation of Article 267 TFEU, (potentially) giving rise to Köbler state liability; but it left that matter for the referring court to decide in the end. Other recent ECJ judgments that indicate a strict approach to CILFIT include AFNE and especially Commission v France mentioned earlier. ${ }^{80}$

There is thus still no certainty as to the exact reach of the CILFIT exceptions. Some recent judgments, such as $X$ and Van Dijk, suggest a relaxation of the requirements; whereas other cases imply an unchanged strict approach. Be that as it may, the legal consequences for national courts' unjustified decisions not to refer are limited in practice. Köbler liability is difficult to establish and the Commission is also reluctant to initiate infringement proceedings on the basis of Article 258 TFEU. ${ }^{81}$ Nonetheless, additional pressure has been exerted on national courts by the European Court of Human Rights (ECtHR). The ECtHR has found a breach of Article 6 of the European Convention on Human Rights - the right to a fair trial - four times since Dhahbi in 2014 due to the failure of the highest courts in some Member States to give reasons for decisions not to refer. ${ }^{82}$ Some EU Member States also provide for constitutional protection of the right to effective judicial protection and provide remedies to challenge decisions of the highest courts. ${ }^{83}$

\section{AN OVERVIEW OF PREVIOUS RESEARCH ON MOTIVES TO REFER}

This book reflects on several theoretical perspectives and tentative explanations that have been formulated in the literature to date, especially in relation to the motives of courts (not) to refer. As was made clear in section 1.1, the empirical research was limited until a few years ago. This book reflects on these explanations qualitatively, in a structured and comparative manner. In doing so, it sheds light on the complex interaction between these explanations.

There are three dominant perspectives in the Europeanization literature on the motives of national courts to refer, which primarily accentuate strategic

\footnotetext{
79 Case C-160/14 Ferreira da Silva EU:C:2015:565, paras 40-42.

80 C-379/15 Association France Nature Environment EU:C:2016:603, paras 48-50.

81 In the Netherlands, there have been six unsuccessful Köbler liability cases since 2014. Van Eijken and Verhoeven 2020, 331.

82 Dhahbi v Italy CE:ECHR:2014:0408JUD001712009; Schipani v Italy CE: ECHR:2015:0721JUD003836909; Baltic Master $v$ Lithuania CE:ECHR:2019: 0416JUD005509216; Sanofi Pasteur v France CE:ECHR:2020:0213JUD002513716; Krommendijk 2017a; Broberg 2016.

83 Lacchi 2015.
} 
or 'extra-legal' factors and considerations. ${ }^{84}$ First, based on neo-functionalist theories on European integration, the judicial empowerment hypothesis posits that national courts refer in order to compel the government to change its laws when they consider that a national measure violates EU law. ${ }^{85}$ The procedure is hence used as a 'sword' vis-à-vis the legislature or executive. Requesting a preliminary reference increases the chances of government compliance with EU law or can be a way to constrain restrictive administrative decision making. ${ }^{86}$ This hypothesis also implies that national courts follow a consequentialist logic and are interested in expanding their own powers and creating the possibility for a form of judicial review, especially in countries with no or a weak tradition of review. ${ }^{87}$ A prominent example of 'sword' references are the Spanish consumer law references in relation to unfair terms in mortgage arrangements. The Aziz reference by Spanish judge and 'judicial entrepreneur' José María Fernández Seijo is a famous example, as he was critical of the financial difficulties that these arrangements caused for people who had failed to meet their mortgage obligations because of unemployment or divorce resulting from the 2008 financial crisis. ${ }^{88}$ Spanish law did not prevent banks from initiating foreclosure, even in case of the nullity of unfair terms. Judge Seijo deliberately brought the case before the ECJ to bring about a change in Spanish law. ${ }^{89}$ This case illustrates that the preliminary reference procedure can function as a sort of 'citizens' infringement procedure', whereby the ECJ acts as a 'court of last resort' for desperate litigants unable to seek legal protection solely at the national level..$^{90}$

Second, neo-realist or intergovernmentalist theories take the opposite stance and argue that national courts have a strong incentive to 'shield' national legislation from the ECJ by withholding references. Courts prefer to shield national policy and legislation from the undesirable influence of the ECJ, especially in politically sensitive cases. ${ }^{91}$ This preference may stem from the national court's loyalty towards the executive; a strong doctrine of parliamentary sovereignty and a weak culture of judicial review; ${ }^{92}$ or the court's resistance to

\footnotetext{
84 Cf Epstein and Knight 2000; Stone Sweet and Brunell 1998, 69; Alter 1998, 232.

${ }_{85}$ Alter and Vargas 2000, 464; Weiler 1991; Weiler 1994, 523; Golub 1996, 379; Davies 2012, 85.

${ }^{86}$ Obermaier 2008; Tridimas and Tridimas 2004, 1215; Rameu 2006; Cornelisse and Moraru 2020, 18 and 35.

87 Burley and Mattli 1993; Mattli and Slaughter 1998; Golub 1996, 376; Alter 1998, 238-41.

88 Mayoral and Pérez 2018.

89 Fernández Seijo 2013; Micklitz and Domurath 2015, 229-37; Cafaggi 2017.

$90 \quad$ Pescatore 2010, 7; Micklitz and Reich 2014, 805.

91 Golub 1996, 375-79; Wind et al 2009; Rameu 2002, 33.

92 Wind et al 2009, 75-76.
} 
the dynamic interpretation of the ECJ. ${ }^{93}$ Some studies also suggest that there is a link between the reluctance of the courts to refer and popular sentiment. Volcansek, for example, argued that the negative sentiment towards the European Community in the 1980s under Thatcher explains the recalcitrance of UK judges to engage with the ECJ through the reference procedure. ${ }^{94}$ Golub likewise concluded that the political climate of Euro-pessimism has affected UK judges in a similar way. ${ }^{95}$

Third, another model - primarily developed in the work of Alter addressing inter-court competition - implies that EU law is used in bureaucratic struggles among different levels of the judiciary. ${ }^{96}$ It points out that lower courts in particular use the preliminary reference procedure to 'leapfrog' the national judicial hierarchy in order to seek support from the ECJ as protection against the reversal of their decisions by a higher court. ${ }^{97} \mathrm{EU}$ law can offer lower courts a 'privilege' that they do not necessarily enjoy domestically - namely, de facto judicial review. ${ }^{98}$ AG Kokott, for example, revealed that the German lower labour courts used the ECJ against the highest court in order to deliver more employee-friendly judgments. ${ }^{99}$ This theory explains why traditionally, most of the references were made by the lower courts in most EU Member States. However, this has changed over time. Recent studies indicate that today, most references are made by the highest courts, while the lower courts have become more reluctant to refer. ${ }^{100}$ The highest courts have thus reclaimed control from the lower courts in relation to the application of EU law in national cases and references to the ECJ. ${ }^{101}$ As will be made clear in section 5, in the Netherlands, the Dutch highest courts have taken the lead in making use of the reference procedure. ${ }^{102}$

The findings presented in this book demonstrate that the emphasis on politico-strategic reasons in the literature is not entirely justified. ${ }^{103}$ The

93 Wind 2010, 1053.

94 Volcansek 1986, 206 and 217.

95 Golub 1996, 377.

96 Alter 1998, 241-47; Burley and Mattli 1993.

97 Davies 2012, 86; 954; Tridimas and Tridimas 2004, 135.

98 Weiler 1991, 2426.

99 Kokott 1998, 128-29.

100 Pavone showed that only the lower courts in Italy have referred the majority of cases, while this is not the case in France, Belgium, the Netherlands or Luxembourg. Pavone 2018; Coutinho 2017, 358; Dyevre et al 2020; Kelemen and Pavone 2016.

101 Pavone 2018; Pavone and Kelemen 2019; Ovádek et al 2020.

102 In the Netherlands, 66 per cent of the references were made by the highest courts; while in 11 Member States, including Belgium, France, Spain and the UK, more than 70 per cent of the references were made by lower courts, Mak et al 2017, 1724.

103 Cf Pavone 2018; Mayoral and Pérez 2018, 723. 
interaction between national courts and the ECJ is not only about 'power' ${ }^{104}$ Legal reasons are equally important as pragmatic reasons, and are sometimes even more important. Much of the earlier work portraying national courts as politico-strategic actors suggest that courts primarily refer in typical - and often high-profile, politically salient - judicial review cases in which national law is not in line with EU law. The majority of references, however, do not involve such questions, but rather boring and technical questions about, for example, the tariff classification of goods or undefined terms in EU legislation. ${ }^{105}$ Five different types of non-politico-strategic considerations may be discerned.

First, there are the legal-formalist reasons: national courts refer because they want to comply with their obligations under the Treaties, most notably Article 267 TFEU. This 'compliance pull' motive, based on the 'power of the law', suggests that courts feel responsible for maximizing the correct application of EU law. ${ }^{106}$ In addition, it presupposes that courts are convinced by legal arguments about, for example, the validity of the doctrine of the supremacy of EU law over national law. With respect to the actual decision to refer in specific cases, the legalistic perspective would point to courts adopting a legal assessment of the clarity of the question of EU law and strictly abiding by the CILFIT requirements, as discussed in section 2 . Unjustified decisions not to refer are seen as unintended mistakes, based on a misunderstanding of limited information. ${ }^{107}$

Second, it has been observed that courts operate pragmatically and do not solely make legal assessments that adhere closely to the CILFIT requirements. ${ }^{108}$ Micklitz argued that judges primarily refer simply because this is necessary for them in order to resolve a national dispute efficiently. If they are unable to interpret EU law on their own, the ECJ may possibly provide the requisite clarity. ${ }^{109}$ Courts thus decide whether a reference is "worth the effort' considering a variety of factors, such as the difficulty or importance of the question in the specific case. ${ }^{110}$ Other efficiency reasons include the consequences of referring in terms of the delay in the specific case or other cases

104 Dyevre 2016, 142.

105 De Werd 2015b; Chalmers and Barroso 2014, 123; Cafaggi 2017, 236. Of the 98 references of the Supreme Administrative Courts in ten Member States 36 involved compatibility questions, van Gestel and de Poorter 2019, 73-75.

106 Weiler 1994, 520; Hübner 2018; Leijon and Glavina 2020.

107 Alter 1998, 230.

108 About 'pragmatic adjudication' more generally, see Posner 2008; Jaremba 2012; Rado 2020, 83; Epstein and Knight 1998; Lampach and Dyevre 2019.

109 Micklitz 2005, 437. Cf Jaremba 2016, 67; Popelier and van de Heyning 2019.

110 De la Mare and Donnelly 2011, 372; Sevenster 2011, 301 and 303; Davies 2006, 230. 
involving the same issue of EU law. ${ }^{111}$ From this perspective, it is unsurprising that courts are generally reluctant to refer and adopt a pragmatic reading of CILFIT.

Third, personal motives and psychological factors have also been put forward more broadly in the literature on judicial decision making. This reflects a recent emphasis on the micro level and the individual agency of judges. ${ }^{12}$ This includes views as to the judge's judicial role and his or her professional attitude and beliefs, such as that only the highest courts should refer. ${ }^{113}$ Such personal views are also affected by the wider culture of judicial review or the attitude towards European integration. ${ }^{114}$ Recent literature has emphasized this factor by pointing to the difference between fact-finding courts, which are generally more reluctant to refer and leave this role to the highest courts, and those courts that have a 'law-finding' role. ${ }^{115}$ Another important (personal) element affecting an individual's judge's inclination to refer is his or her knowledge of EU law and/or the preliminary reference procedure. ${ }^{116}$ The literature has also - often in a rather anecdotal way - pointed to personal motives such as self-aggrandizement, prestige and increased visibility at the European level. ${ }^{117}$ The flip-side is that some judges consider that a reference would be risky or negative for their reputation. ${ }^{118}$ It has been suggested that some judges are afraid to ask a wrong question that would subsequently be declared inadmissible by the ECJ. ${ }^{119}$ Other scholars have noted that judges might be discouraged from referring because they fear a negative response from their colleagues, other courts or the legislature. ${ }^{120}$

A fourth category of factors relates to the institutional and organizational dynamics of a particular court. These include, for example, the level of coordination and the knowledge basis in relation to EU law within a court; the court's capacity; and the case management system. With respect to the latter, it has been pointed out that the need to meet 'production targets' and

111 Wind 2009, 283; Jaremba 2012, 229.

112 Posner 2008; Epstein et al 2013; Chehtman 2020; Rado 2020; Lampach and Dyevre 2020.

113 Jaremba 2012, 229; Pavone 2018.

114 Wind et al 2009; Dyevre 2013, 152.

115 Glavina 2019 and 2020a; Rameu 2002, 12-13; Stone Sweet and Brunell 1998, 73.

116 Nowak et al 2011, 49; Rytter and Wind 2011, 493; Glavina 2020b.

117 Spanish judge in Burgorgue-Larsen 2015; Leijon and Glavina 2020.

118 Wattel 2014, 893.

119 Jaremba 2012, 229-30; Sevenster and Wissels 2016, 90; Groenendijk 2015, 302.

120 Lampach and Dyevre 2019. 
workload pressures have discouraged references. ${ }^{121}$ Pavone concluded, based on thorough empirical research conducted in Italy, Germany and France, that (a lack of) references can be explained by path-dependent, everyday practices within national courts. ${ }^{122}$

Fifth, the literature has also noted that the parties involved in a national case and their requests to refer can influence the courts' willingness to refer. ${ }^{123}$ More generally, the amount of litigation in a certain area can explain the likelihood of references being made. ${ }^{124}$ This focus on the parties dovetails neatly with research on legal mobilization and strategic litigation on the basis of EU law. ${ }^{125}$ It is an often-told story that the preliminary reference procedure, coupled with supremacy and direct effect, has stimulated an 'indirect alliance' between litigants and pro-integration forces such as the ECJ. ${ }^{126}$ Older references in particular have been attributed to a small group of Euro-lawyers as 'legal entrepreneurs' with strong pro-EU views pushing for further integration and the development of EU law. ${ }^{127}$ Pavone attributed 60 of the 89 Italian references in the period 1964-80 to the same four lawyers, including a former ECJ judge. ${ }^{128}$

This overview has shown that an abundance of factors and considerations feed into courts' decisions (not) to refer, including three extra-legal politico-strategic reasons and five non-politico considerations. The following chapters will discuss these explanations on a structured basis. In doing so, this book reveals that these considerations operate in tandem in an intricate and diverse way, which could explain the variations among and within Member States, over time and across policy areas.

\section{RESEARCH DESIGN AND METHODOLOGY}

This book goes beyond a merely descriptive and taxonomical account and also aims to provide explanations. A legal analysis of court decisions, as explained in section 4.2, is therefore insufficient. ${ }^{129}$ Merely relying on (national) court

121 Groenendijk 2015; Nowak et al 2011, 54; Jaremba 2012, 229-30; Prechal et al 2005, 25; Glavina 2020b; Leijon and Glavina 2020.

122 Pavone 2018. Cf Jaremba 2016, 49; Hübner 2018.

123 Wind 2010, 1053; Wind et al 2009, 283; Passalacqua 2021.

124 Hoevenaars 2018; Stone Sweet and Brunell 1998, 88; Cichowski 2007.

125 Conant 2006; Conant et al 2018; Vauchez and de Witte 2013; Nicola and Davies

2017; Stone Sweet 2004; Kelemen 2011.

126 Pollack 2017, 582; Dehousse 1998, 47.

127 Vauchez 2015; Rasmussen and Martinsen 2019, 261-62; Pollack 2017, 583; van Leeuwen 2018.

128 Pavone 2020.

129 Cf Mak 2013. 
judgments might give the impression that the procedure functions flawlessly and that national courts are satisfied with the ECJ. The combination of legal research and semi-structured interviews (section 4.3) makes it possible to identify what national court judges actually $d o$ and think. The qualitative research design is best suited to capture 'more fine-grained' processes at the micro level and find out why judges refer (or not) and whether they appreciate the resulting ECJ judgments. ${ }^{130}$ This section will first provide a justification of the selection of three states (section 4.1), before the methodology regarding the case law analysis and interviews is explained.

\subsection{Selection of the Netherlands, Ireland and the UK}

To answer the four research questions, a small number of countries were systematically examined. Such a small-N study is the most prevalent method in social science and comparative public law. ${ }^{131}$ A most different systems design was adopted and three countries with a different approach to referring were selected: the Netherlands, Ireland and the UK. ${ }^{132}$

The choice of these three countries was based on a preliminary categorization of three groups of Member States based on the relative number of references per EU Member State in the period 2009-15 - namely, the number of references per million inhabitants. ${ }^{133}$ It should immediately be noted that a reliance on numbers and referral rates is problematic. The number of references tells us very little. First, a high number of references is not necessarily a sign of a cooperative attitude; ${ }^{134}$ it could also suggest that national courts merely treat the ECJ as a 'helpdesk', without investing time and energy in considering EU law questions themselves. A reference can also be made to challenge the ECJ or the content of specific EU rules (Chapter 7, section 4). ${ }^{135}$ Second, in some EU Member States, the courts submit similar cases jointly; while in others, they are referred separately, as a result of which the number of referred cases

130 Bennett and Elman 2006; Hall and Wright 2008.

131 Mahoney 2000.

132 Hirschl 2014.

133 Croatia, Poland, the UK, France, the Czech Republic, Greece, Sweden, Spain, Italy, Romania, Slovakia and Slovenia were in the group with relatively few references (0-0.9); Germany, Malta, Portugal, Finland, Ireland, Denmark, Lithuania and Hungary were in the group with 1-1.5 references; and Cyprus, the Netherlands, Bulgaria, Estonia, Austria, Belgium, Latvia and Lithuania were in the group with more than 1.9 references.

134 Vink et al 2009, 6.

135 Eg references by the UK and Dutch Supreme Court in relation to the Brussels I Regulation in Case C-185/07 West Tankers EU:C:2009:69; Case C-681/13 Diageo Brands EU:C:2015:471; Kramer 2019. 
increases quickly. ${ }^{136}$ The relative number of references is thus nothing more than a rough indicator. These figures were thus complemented by (anecdotal) information about the acceptance of EU law and the level of engagement with the ECJ in particular Member States. The official language in Member States was also an important additional consideration, as solid language proficiency is necessary to carry out a detailed legal analysis of actual judgments as well as the interviews. ${ }^{137}$

The following can be said about the approach towards the preliminary reference procedure in the three selected countries. The UK courts have made relatively little use of the preliminary reference procedure. Golub observed back in 1996 that UK judges are loath to refer. ${ }^{138}$ By contrast, the Dutch courts refer a significant number of questions, in both relative and absolute terms, and are eager to engage with EU law. ${ }^{139}$ Ireland is positioned somewhere in between the two. Fahey observed in 2007 that the Irish courts had yet to begin a dialogue with the ECJ, but the numbers since then show that the Irish courts have caught up and now rank in the middle. ${ }^{140}$ While only 44 cases were referred in Ireland's first 30 years of EU membership (1973-2003), 45 references were made in the six years between $2013-18 .{ }^{141}$ The latter partly reflects the fact that the position of EU law within Irish courts has been characterized as 'pro-Communautaire' and cooperative. ${ }^{142}$

\subsection{The Legal Analysis of Judgments}

The first important part of this research is the case law search, coupled with a qualitative analysis of national court and ECJ judgments. In all three Member States, all decisions (not) to refer in the period from 1 January 2013 to 31 December 2016 were analysed. ${ }^{143}$ This does not mean that relevant developments prior to 2013 and after 2016 were not considered; but they were not

136 Broberg and Fenger 2013, 501.

137 Mak 2013; language barriers were reported as an obstacle by van Gestel and de Poorter 2019, 108.

138 Golub 1996, 368. Cf Broberg and Fenger 2013, 500.

139 Claes and de Witte 1998; Broberg and Fenger 2013, 492; van Leeuwen 2018; Rasmussen and Martinsen 2019, 264-65.

140 Fahey 2007, 142-43.

141 Krommendijk 2020.

142 Fahey 2007, 2; Maher 2018, 177-78 and 185; Butler 2017, 108; Collins 2018, $12-13$.

143 This period was chosen to examine the most recent situation possible, while also enabling the analysis of the answers of the ECJ and their implementation by the referring court. Cf van Gestel and de Poorter 2019, 60. 
examined on a structured basis. In order to find all decisions (not) to refer, ${ }^{144}$ a systematic search of case law databases with published judgments was conducted using carefully selected search terms. ${ }^{145}$ By using search terms such as '267 TFEU' and 'CILFIT', decisions (not) to refer were found in which the court explicitly considered that there was (no) reason to refer (see Table 1.1).

The disadvantage of this approach is that so-called 'silent cases', in which the court did not engage with the question of whether to refer, could not be retrieved easily. ${ }^{146}$ Such judgments are obviously equally or even more interesting to consider, especially when a reference was appropriate but the court intentionally avoided the matter. To find silent cases, two strategies were adopted. First, the literature and legal commentaries were used to identify cases that had been criticized by scholars for non-referral. Second, in cases in which a higher or highest court made a referral, the prior decisions of the lower courts were also examined. ${ }^{147}$

This case law search yielded a selection of judgments. All cases were closely scrutinized in terms of the reasoning employed by the courts in relation to the question of whether to refer. To answer the question on follow-up and satisfaction, the national court's follow-up judgment was compared with the requested ECJ ruling in order to establish whether and how that court applied the ECJ judgment. Secondary literature and commentaries were useful in conducting this analysis because they often revealed criticism regarding the reasoning and approach of the ECJ and/or follow-up by the referring court.

\subsection{Interviews and Their Limitations}

A doctrinal legal analysis alone would have been insufficient to answer the four research questions, since court judgments are often silent on other relevant considerations and calculations beyond purely legal (formalist) reasons. Semi-structured interviews thus played an important complementary role in

144 The website of the ECJ (https://curia.europa.eu/) was used as a complementary source, since not all decisions to refer or orders for reference are published as judgments in national court databases.

${ }_{145}$ Searches conducted on www.rechtspraak.nl for 'prejudiciële vragen', 'CILFIT' and '267 VWEU'; and on www.bailii.org for 'preliminary ruling', 'preliminary reference', 'CILFIT', '267 TFEU' and 'article 267' for the period 1 January 2013 to 31 December 2016.

146 As a result of the case law of the ECtHR mentioned earlier, the number of such 'silent' judgments seems to have reduced. It seems that the highest courts have been more willing in recent years to provide detailed reasons as to why a reference is not necessary where one of the parties requested a reference as a result of the case law of the ECtHR.

147 Arnull 2010, 73. 
Table $1.1 \quad$ Number of references, decisions not to refer and silent cases (2013-16)

\begin{tabular}{|c|c|c|}
\hline Dutch courts & Number of references ${ }^{1}$ & $\begin{array}{c}\text { Decisions not to refer } \\
{\text { silent } \text { cases }^{2}}^{2}\end{array}$ \\
\hline Council of State & 22 & 74 \\
\hline Central Appeals Tribunal & 13 & 16 \\
\hline Trade and Industry Appeals Tribunal & 10 & 22 \\
\hline Supreme Court (SC) & 49 & 75 \\
\hline - Tax Chamber SC & 36 & 23 \\
\hline - Civil Chamber SC & 12 & 33 \\
\hline - Criminal Chamber SC & 1 & 19 \\
\hline Internationale Rechtshulpkamer & 7 & 11 \\
\hline Courts of appeal & 9 & 90 \\
\hline District courts & 19 & 192 \\
\hline Total & 129 & 480 \\
\hline \multicolumn{3}{|l|}{ UK courts } \\
\hline Supreme Court & 7 & 20 \\
\hline Court of Appeal & 14 & 52 \\
\hline High Court & 21 & 46 \\
\hline - Chancery & 6 & 17 \\
\hline - Administrative/Queen's Bench & 13 & 24 \\
\hline - Commercial & 0 & 4 \\
\hline - Family & 2 & 1 \\
\hline Upper Tribunal & 7 & 21 \\
\hline - Immigration and Asylum & 2 & 10 \\
\hline - Tax and Chancery & 5 & 11 \\
\hline First Tier Tribunal $(\operatorname{tax})^{3}$ & 13 & 15 \\
\hline Scottish Court of Session & 1 & 9 \\
\hline Other courts and tribunals & $4^{4}$ & 10 \\
\hline - Employment Appeal Tribunal & 0 & 8 \\
\hline Total & 67 & 173 \\
\hline \multicolumn{3}{|l|}{ Irish courts } \\
\hline Supreme Court & 8 & 6 \\
\hline Court of Appeal (since October 2014) & 4 & 7 \\
\hline High Court & 8 & 29 \\
\hline Circuit courts & 0 & $*$ \\
\hline District courts & 1 & $*$ \\
\hline Other statutory tribunals ${ }^{6}$ & 2 & $*$ \\
\hline
\end{tabular}




\begin{tabular}{lcc}
\hline Dutch courts & Number of references & $\begin{array}{c}\text { Decisions not to refer/ } \\
\text { silent cases }^{2}\end{array}$ \\
\hline - Labour Court & 1 & $*$ \\
\hline - Tax Appeals Commission & 1 & $*$ \\
\hline Total & $\mathbf{2 3}$ & $\mathbf{4 2}$ \\
\hline
\end{tabular}

Notes:

1. Similar cases referred by the same court that were later joined by the ECJ were counted as one. In addition, the moment at which the court decided to refer was determinative and not the date of registration at the ECJ. These decisions could explain why the numbers differ from those in the ECJ's annual report (eg, 142 for the Netherlands instead of 129 and 65 instead of 67 for the UK). 2. Judgments involving the same (legal) issue and containing (roughly) identical substantive reasoning, but involving different applicants, were counted as one. Eg NL:HR:2014:279; NL: HR:2014:327; NL:HR:2014:329. 3. The only non-tax decision to refer was [2014] UKFTT EA_2013_0037 (GRC). 4. Employment Tribunal Birmingham (Case C-219/14EU:C:2015:745); Supreme Court of Gibraltar (Case C-267/16EU:C:2018:26); Industrial Tribunals (Northern Ireland) (C-182/13EU:C:2015:317); Scottish Land Court (C-335/13EU:C:2014:2343). 5. The Court of Appeal commences operations on 28 October 2014 and sits between the High Court and the Supreme Court. It was created with the aim of reducing the backlogs at the Supreme Court. 6. Other statutory bodies include the International Protection Appeals Tribunal, the Employment Appeals Tribunal and the Equality Tribunal (currently the Workplace Relations Commission). The former two have never referred, while the latter referred CaseC-363/12EU:C:2014:159.

distilling the 'true' appraisal of the answers from the ECJ in the national courts' follow-up judgments. Interviews were conducted with judges (and sometimes AGs or legal assistants) who did and did not refer (see Table 1.2). Interviewees were chosen on the basis of their involvement in both cases in which a reference was made and cases in which the court decided not to refer. To select the interviewees, an overview was made of every judge's involvement in these cases. Interviewing judges with no experience in referring ensured that a representative picture was provided. This prevented a common omission in research, whereby only stakeholders who are generally positively disposed towards a certain phenomenon are interviewed - in this case, judges who have referred a lot and are generally positive about their experience with the ECJ. ${ }^{148}$ In both the UK and Ireland, supplementary interviews were also conducted with legal practitioners, due to the importance of the litigants' legal teams in framing the questions referred. These Euro-laywers were also able to reflect on the referral practice of national courts. ${ }^{149}$

Approval for the interviews was obtained in advance from the president of the court or the council for the judiciary. No permission was granted to interview judges in the UK aside from a collective written response from the

148 Cf Bobek 2013a.

149 Cf Pavone 2018. 


\section{Table $1.2 \quad$ Overview of interviewees}

\begin{tabular}{|c|c|}
\hline Dutch courts & Number of interviews \\
\hline Council of State & 6 \\
\hline Central Appeals Tribunal & 5 \\
\hline Trade and Industry Appeals Tribunal & 5 \\
\hline Supreme Court (SC) & 15 \\
\hline - Tax Chamber SC & $8^{1}$ \\
\hline - Civil Chamber SC & 7 \\
\hline - Criminal Chamber SC & $0^{2}$ \\
\hline Internationale Rechtshulpkamer & 2 \\
\hline Courts of appeal & $\begin{array}{c}6 \text { (2 no reference } \\
\text { experience) }\end{array}$ \\
\hline District courts & $\begin{array}{c}16 \text { (8 no reference } \\
\text { experience) }\end{array}$ \\
\hline Total & 54 \\
\hline \multicolumn{2}{|l|}{ Irish courts } \\
\hline Supreme Court & 5 \\
\hline Court of Appeal & 3 \\
\hline High Court & $\begin{array}{c}11 \text { (5 no reference } \\
\text { experience) }\end{array}$ \\
\hline Circuit courts & $\begin{array}{c}1 \text { (1 no reference } \\
\text { experience) }\end{array}$ \\
\hline District courts & 1 \\
\hline Other statutory tribunals & $\begin{array}{c}3 \text { (1 no reference } \\
\text { experience) }\end{array}$ \\
\hline Practising lawyers and academics & $3 \& 1$ \\
\hline Total & 28 \\
\hline \multicolumn{2}{|l|}{ UK courts } \\
\hline Supreme Court & 3 \\
\hline Practising lawyers & 3 \\
\hline Total & 6 \\
\hline
\end{tabular}

Notes:

1. One interviewee served in both chambers. 2. Four interviewees with no reference experience were interviewed by Claassen in the context of his $\mathrm{PhD}$ (forthcoming in 2022). 
Supreme Court and interviews with three former Supreme Court judges. ${ }^{150}$ The relatively low number of interviews in the UK was not problematic, however, since the judgments of UK courts are relatively transparent about (non-legal) reasons not to refer and judges have been open in extra-judicial speeches and writings. ${ }^{151}$ Almost all judges and court clerks who were approached for an interview were willing to cooperate. ${ }^{152}$ Interviews took place between September 2016 and January 2018 (the Netherlands), between September and December 2018 (Ireland) and in March 2020 (UK). In order to protect the anonymity of interviewees, their names and identities have not been disclosed. ${ }^{153}$

Questions during interviews (see Box 1.1) were raised in an open way and were initially phrased in general terms. Judges were thus encouraged to discuss specific cases on their own initiative. Interviewees were subsequently questioned about specific cases that were identified during the doctrinal analysis and that had not been mentioned by the interviewees themselves. Hence, interviewees had the freedom to come up with motives and factors on their own initiative without being directed too much. At a later stage of the interview, interviewees were asked to reflect on motives discussed in the literature (section 3). They were also asked about their reasons not to refer questions in the silent cases that were criticized in the literature or that were subsequently referred by a higher court. This interview set-up - starting with open-ended questions, followed by more closed questions and probing - is in line with established social science methods. ${ }^{154}$

\section{BOX 1.1 INTERVIEW QUESTIONS}

1. Question: Which considerations play a role in decisions (not) to refer to the ECJ? What reasons (not) to refer are given in particular cases? How are the CILFIT exceptions interpreted and applied?

150 The reasons given by the Judicial Research Requests Office were that interviews are not a good use of judicial resources due to the fact that much of the information can be found in the judgments of these cases. In addition, the narrowness of the judicial selection means that cases are too easily identified.

151 Arden 2010, 2014 and 2015; Arnold 2020; Mance 2011, 2013a, 2013b and 2015; Neuberger 2016; Reed 2014.

152 One Irish judge interviewed withdrew from the study; three Irish candidates could not be contacted or did not respond; and one was unable to meet.

153 A number between 0 and 100 was randomly selected for the interviews. Note that references to interview numbers are omitted when specific cases are discussed, because this would make it possible to trace the identity of the interviewees on the basis of the published judgments.

154 Cf Bos 2020, 34. 
2. Answer: What is your appraisal of the requested ECJ judgments? Is the reasoning of the ECJ sufficiently clear? Can ECJ judgments be applied easily in the national court case in order to resolve the dispute?

3. Follow-up: How have the ECJ judgments been complied with? Are there cases of incomplete follow-up, and why?

4. Feedback loops: To what extent are the expected answers of the ECJ taken into account when deciding (not) to refer?

There are obviously limitations to interviews as a research method, especially when it comes to determining (personal) motives. ${ }^{155}$ Answers often constitute retrospective ex post rationalizations and it is often unclear whether the considerations really played an (important) role at the time of the decision making. ${ }^{156}$ It may also be the case that interviewees give socially desirable answers and/ or exaggerate or minimize the relevance of certain reasons because this better corresponds to their own (desired) self-image. Judges may also be reluctant to acknowledge that politico-strategic reasons played a role in their decision (not) to refer and may conceal their engagement in such strategies. Such strategies could conflict with their self-perception or professional ethos as an independent judge who decides purely on the basis of the law. Despite the secrecy of judicial deliberations, interviewees were relatively open, seemed honest and were willing to discuss individual cases. This reflects the experience of van Gestel and de Poorter in interviewing judges in ten supreme administrative courts. ${ }^{157}$ Questioning and probing interviewees about specific cases and judgments forced some judges to backtrack on their initial overly positive views. ${ }^{158}$

In order to mitigate these problems, the following strategies were adopted. First, a recent time period (2013-16) was chosen, to assist interviewees in accurately reconstructing the actual considerations at the time of decision making. Second, interviewees were encouraged not to reflect on motives in general and in abstracto, but always to give concrete examples and/or reflect on specific judgments that were identified during the legal analysis. Third, ideally, more than one judge involved in a particular important case was interviewed in order to cross-check certain pronouncements. This proved especially feasible for judgments of the highest courts with a chamber of five judges. Fourth, an attempt was made to 'triangulate' the data obtained from the

\footnotetext{
155 'Asking someone to identify his or her motive is one of the worst methods of measuring motives', Epstein and King 2002, 93.

156 Cf Bos 2020, 43.

157 Cf experience with interviewing judges in the Supreme Administrative Courts by van Gestel and de Poorter 2019, 107.

158 Cf Bobek 2013a, 72.
} 
interviews as much as possible with other sources, such as court judgments, extra-judicial speeches and writings of judges, and secondary literature. ${ }^{159}$

\section{INTRODUCTION TO THE THREE SELECTED MEMBER STATES}

Before delving into the practice in the three selected countries, it is important to provide some context and background regarding the legal systems in these countries. This short overview reveals that comparisons between them are often difficult to make. In the Netherlands, there are three levels within the judicial hierarchy: the Supreme Court and three different supreme administrative courts; four courts of appeal; and 11 district courts. The highest administrative courts are second-line courts of fact, while the Supreme Court is the third-instance cassation court, which examines questions of law only. The Dutch Supreme Court also functions differently from the UK and Irish Supreme Court, in that it grants permission to appeal only when a case involves 'an arguable point of law of general public importance'. ${ }^{160}$

The situation is more complicated and confusing in Ireland, and especially in the UK, as there are more court levels and a wide variety of courts and tribunals. ${ }^{161}$ It is difficult to compare these multiple levels to the Dutch situation. In Ireland, there are at least five levels: the Supreme Court; the Court of Appeal; the High Court; eight circuit courts; and 23 district courts; plus several statutory tribunals that do not 'traditionally fit into the judiciary'. ${ }^{162}$ The UK also has several lower courts - crown, magistrates, county and family courts, including highly specialized upper and first-tier tribunals - beyond the three superior or intermediate appellate courts (the Supreme Court; the Court of Appeal; and the High Court). What further complicates the UK system is that it does not have a single unified legal system, but consists of three systems: England and Wales, Scotland and Northern Ireland. The UK Supreme Court, which replaced the House of Lords as of 1 October 2009, sits above all three in most cases as the ultimate court of appeal.

There is a considerable difference between the Netherlands on the one hand and Ireland and the UK on the other, in terms of the ratio between references of the highest and lowest courts. Just 35 of 129 (27 per cent) Dutch references in the four-year period came from the lower courts. These figures suggest that the highest courts take the lead in the Netherlands. All of the four highest

159 Ibid

160 Feteris 2017, 157; Mak 2015.

161 www.judiciary.uk/about-the-judiciary/the-justice-system/court-structure.

162 Butler 2017, 109. 
Dutch courts are repeat players in the preliminary reference procedure and have become important interlocutors of the ECJ. For all three of the highest administrative courts, EU law plays an important role in the areas over which they have jurisdiction: economic public law (the Trade and Industry Appeals Tribunal); migration (the Administrative Division of the Council of State); and social security (the Central Appeals Tribunal). The Tax Chamber of the Supreme Court is the most active Dutch court in terms of the absolute number of references and also refers frequently compared to other European tax courts. The Civil Chamber is also increasingly confronted with EU law, especially in the fields of intellectual property (IP), consumer law, competition law and private international law. The Criminal Chamber is the sole exception in this picture, given the limited number of references and, as will be discussed later, its reluctance to engage with the ECJ.

By contrast, 15 out of 23 (65 per cent) of Irish references and 60 out of 67 (90 per cent) UK references were made by 'lower' courts other than the highest Supreme Court, especially the Court of Appeal and the High Court and, in the case of the UK, also several specialized (tax) tribunals. The lower number of Supreme Court references in the UK and Ireland is unsurprising, considering the leave to appeal system and the relatively low number of cases that these courts handle on a yearly basis. In sum, one should be careful when comparing mere numbers, because the differences in these judicial systems as discussed above mean that one would quickly end up comparing apples and oranges. 